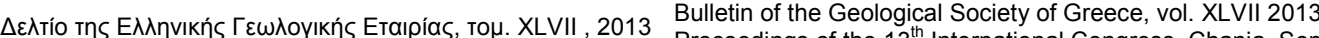
Proceedings of the $13^{\text {th }}$ International Congress, Chania, Sept.

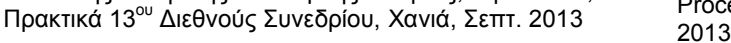

\title{
REMOTE SENSING TECHNIQUES AS A TOOL FOR DETECTING WATER OUTFLOWS. THE CASE STUDY OF CEPHALONIA ISLAND
}

\author{
Stefouli M. ${ }^{1}$, Vasileiou E. ${ }^{2}$, Charou E. ${ }^{3}$, Stathopoulos N. ${ }^{2}$, Perrakis A. ${ }^{3}$ and \\ Giampouras P.
}

\author{
${ }^{1}$ National Center of Sustainable Development, Unit of Environmental Policies, 241 Kifisias \\ Avenue Vila Kazouli, 14561, Greece. stefouli@igme.gr \\ ${ }^{2}$ National Technical University of Athens, School of Mining \& Metallurgical Engineering, \\ Laboratory of Engineering Geology \& Hydrogeology, Heroon Polytechniou 9, 15780, Athens, \\ Greece.,elvas@metal.ntua.gr,nstath@metal.ntua.gr \\ ${ }^{3}$ National Center for Scientific Research - Demokritos, Institute of Informatics and \\ Telecommunications, Computational Intelligence Laboratory, 153 10, Agia Paraskevi, Athens \\ Greece.exarou@iit.demokritos.gr,perrakisandreas3@gmail.com parisg@iit.demokritos.gr
}

\begin{abstract}
The amount of water flowing into the seas and oceans has slowly but steadily increased in recent years, signifying a possible speeding up of the water cycle due to climate change. The detection of the water outflows and the exploitation of them are very important to the rational water management. Remote sensing techniques has been proven a valuable tool for the detection and identification of submarine groundwater discharge-SGD (Submarine Groundwater Discharge). In this study the island of Cephalonia in Ionian sea, Greece is considered as a case study. A 6 Km sea buffer zone around the island is studied using Landsat images. Submarine groundwater discharge has been detected through remote sensing methods and the results have been combined with the tectonism and hydrogeological conditions of the island. A quantitative analysis of temperature in the buffer zone was carried out. The sea thermal anomalies in the same zone were also investigated.

Key words: submarine springs, Ioanian sea, karstic system, GIS, Landsat, Thermal Infrared.
\end{abstract}

\section{Пврі́ $\eta \psi \eta$}

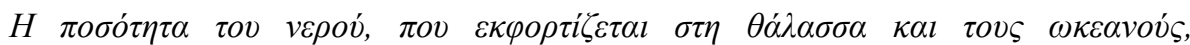

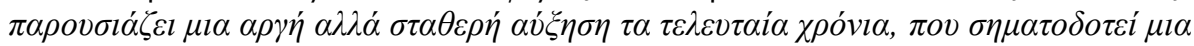

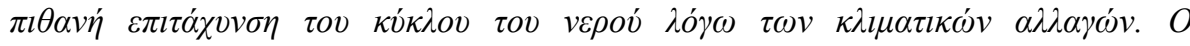

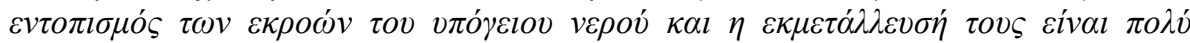

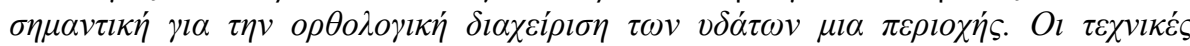

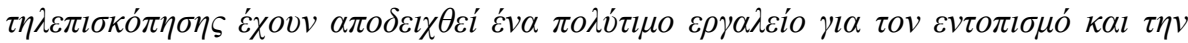

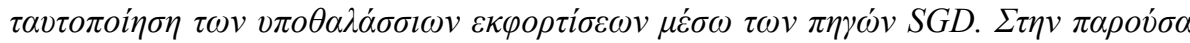

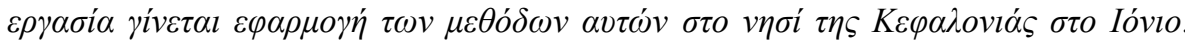

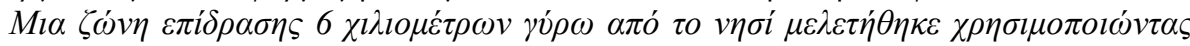

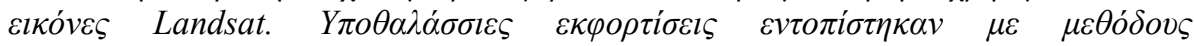




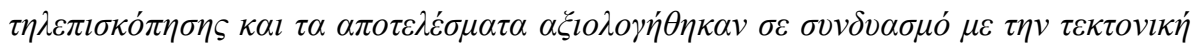

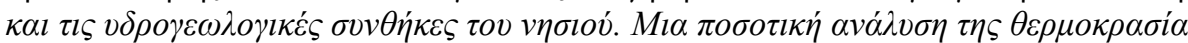

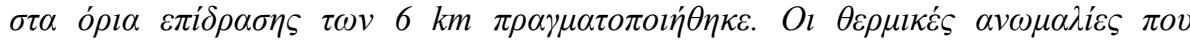
$\varepsilon \mu \varphi \alpha v i \zeta o v \tau \alpha l \sigma \tau \eta \zeta \omega ́ v \eta \alpha v \tau \dot{~} \delta \varepsilon \rho \varepsilon v v \dot{\theta} \theta \eta \kappa \alpha v$.

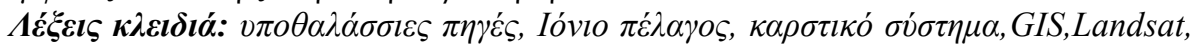

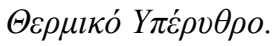

\section{Introduction}

GIS and Remote Sensing are powerful tools which provide solutions for water resources problems; such as assessing water quality, determining water availability, managing flood problems, understanding the natural environment, and managing water resources on local and regional levels.

Coastal aquifers have the tendency to discharge their subsurface flow into the sea either through seepage or submarine springs where fractures prevail. Karstic aquifers may have hydraulic links with the sea resulting in dominant flow of submarine springs. These springs were known to exist since the time of the Phoenicians (1000 years ago) where they used submarine springs. Recently submarine springs were discovered by divers and described by scientists in many countries such as Greece, France, Libya, Italy, Spain and South America and some other areas in the world. Although these springs are well documented no attempts were made to survey these areas in order to locate these springs (Al Bassam, 2005).

A basic driver of freshwater SGD is the amount of rainfall received by the drainage basin, coupled with evapo-transpiration rates and the surface geology (particularly the surface infiltration capacity) but flow through coastal marine sediments can occur for a variety of reasons. Flow may be induced by the terrestrial hydraulic gradient as well as by marine processes such as wave set-up, tidally driven oscillations, density-driven convection, and thermal convection(Al Bassam, 2005).

The mix will be different in different regions. It will depend, for example, on the hydraulic conductivity, hydraulic head, groundwater catchment area, recharge rates and many other factors. Density-coupled modelling of the saltwater interface indicates that seawater recirculation rates of $60 \%$ and more can occur due to dispersion and mixing within the aquifer even when wave and tidal effects are ignored. Since wave-induced and tidal effects are rarely completely absent, a great deal of seawater recirculation must occur on a global scale, while the local effects of freshwater SGD can be dominant in near shore environments (Al Bassam, 2005).

Coastal aquifers have the tendency to discharge their subsurface flow into the sea either through seepage or submarine springs where fractures prevail. Karstic aquifers may have hydraulic links with the sea resulting in dominant flow of submarine springs.

The contribution of the remotely sensed data to the geologic / geomorphologic mapping and identification of changes of fresh water outflow through time is indicated with the processed satellite imagery for the pilot project area.

This paper is organized into the following 4 sections. Section 2, presents the GeologyHydrogeology of the study - pilot area, the Cephalonia island, Greece. Section 3 describes the data set and the methodology used, the main pre-processing techniques adopted and Section 3 describes and discusses the experimental results obtained. Finally, Section 4 draws the conclusion of this paper.

\section{Study-Pilot Area, Cephalonia Island}

Cephalonia Island is used as pilot project area of study. The island is located in western Greece, in the Ionian sea. It covers a land of $781 \mathrm{~km}^{2}$ and it has about 35.000 habitants and important touristic development (IGME, 2010). The hydrogeological conditions of the area are very complex. The

XLVII. No $3-1520$ 
island could be characterized as mountainous in the major part of the land. Different karstic systems create a very interesting hydrodynamic regime, with high capacity aquifers, spring discharges and water outflows in the sea around it. Submarine springs have been detected through remote sensing methods. The detection of the water outflows and the exploitation of them are very important to the rational water management of the island.

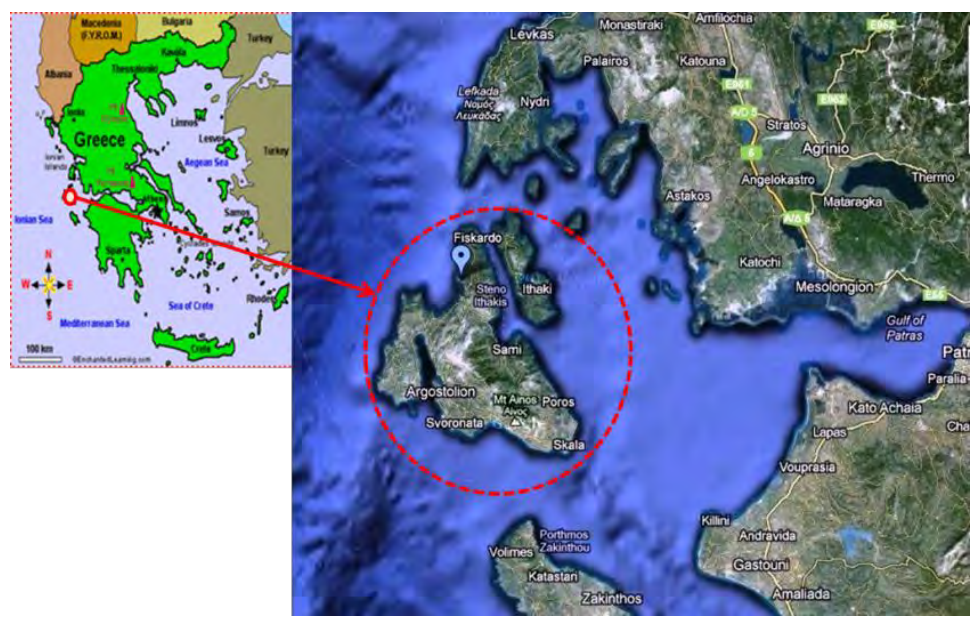

Figure 1 - The study area (www.googlemap.gr).

\subsection{Geology-Hydrogelogy of Cephalonia}

Cephalonia Island belongs to Paxos and Ionios geotectonic zones. Paxos zone covers the widest part of the island. The main formations of the zone are the limestones of the Upper Cretaceous and smaller lanes of Paleocene and Eocene limestones. The Lower Cretaceous appears in small extent, with dolomitic limestones and dolomites in the area of Asos. Above the more recent limestones of this carbonic series, there are Oligocene and Miocene formations consisting of marbles, clays, or alternations of them with sandstones, conglomerates and limestones. In the eastern part of the island (Sami - Skala) the formations of the Ionian zone are overthrusted to Miocene deposits of Paxos zone (IGME, 2010).

The island's developing formations, from the more recent to the older ones, are the following:

- Alluvium and scree of the Oligocene

- Sandstones and conglomerates of the Pleistocene

- Conglomerates, sandstones and limestones of the Pliocene

Formations of Paxos Zone

- Conglomerate and lacustrine limestone of the Upper Oligocene - Upper Miocene

- Limestones Eocene - Oligocene

- Limestones Paleocene

- Limestones of the Upper Cretaceous

- Dolomites and limestones of the Upper Cretaceous

Formations of Ionian Zone

- Limestones of the Eocene

- Limestones of the Paleocene

- Lacustrines and limestones of the Upper Cretaceous

- Viglae limestones of the Upper Jurassic - Lower Cretaceous

- Schist and limestones of the Middle and Upper Dogger

- Pantocrator limestones of the Upper Trias - Middle Lias

XLVII. No $3-1521$ 
As it is shown in geological map (Figure 2), there are many faults in total extent of Island. The main directions of the faults are NNW-SSE, N-S, NE-SW and E-W. Because of the actions of these faults, there is the tectonic sink of Argostoli bay and the lagoon of Koutavos.

The Island is mainly covered by carbonate formations, which are permeable. Because of the extended development of permeable formations, there is not significant surface run off, the total volume of rainfall infiltrates and recharges the karstic aquifers. The karstic systems of the Island are very complex because of the intense tectonism.

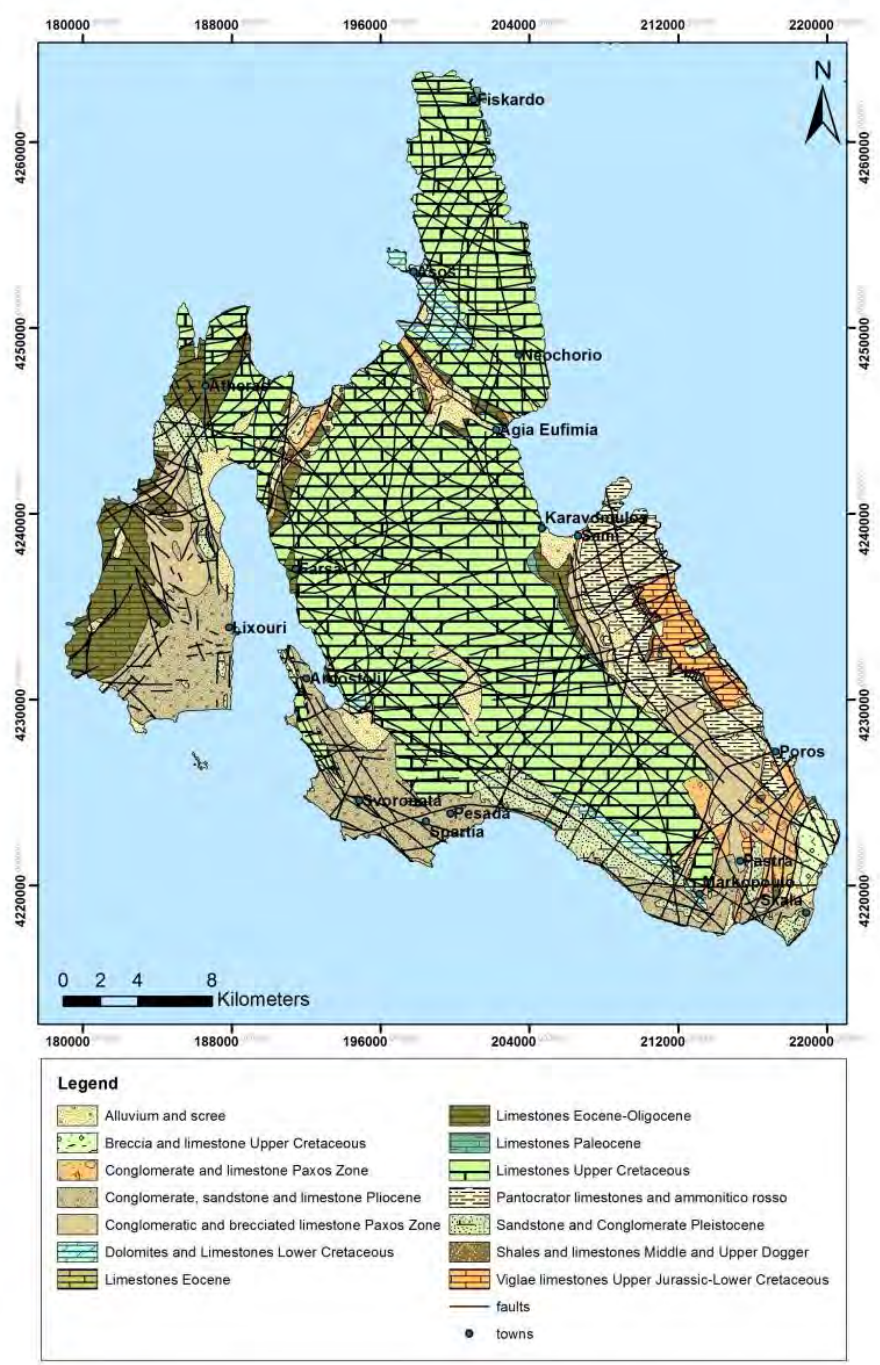

Figure 2 - Geological map of Cephalonia Island.

Six different karstic systems are developed in the Island. The karstic system of mountain Ainos (Ionian zone) is discharged by three coastal springs. These karstic systems have significant outflows to the sea, which are very difficult to quantify them. According to Koumantakis (1989), the most significant springs in the Island are : a) Springs of Agios Ioannis $\left(200 \mathrm{~m}^{3} / \mathrm{h}\right)$ b) Papadatos springs $\left(300 \mathrm{~m}^{3} / \mathrm{h}\right)$ in Koutavos, c)Springs of Avuthos $\left(100 \mathrm{~m}^{3} / \mathrm{h}\right)$, d) In the Sami moorage, the saline springs of Karavomilos and Agia Eufimia. All these springs are the surface discharge points from the respectively karstic systems, but there are also many submarine springs with significant outflows to the sea. The karstic system of mountain Atros is discharged surficial by Avuthos springs. The karstic system of Kalo Oros, at the north part of Cephalonia is exploited by drills and 
it is in hydraulic connection by the sea. Outflows come also from the karstic sytem of Paliki, at the area of Aitheras. In Lixouri it is developed a semi-aquifer system in the alluvial deposits. In Argostoli there is a granular water system, confined and unconfined aquifers are developed.

The average annual precipitation in Cephalonia Island was estimated at about $890 \mathrm{~mm}$ for the period 1955-2008 in meteorological station of Argostoli. The evapotranspiration was estimated at $48 \%(427 \mathrm{~mm})$ of the total precipitation. The surface flow and infiltration is about $52 \%$ of the rainfall, groundwater drainage is about the $43 \%$ of this amount (IGME, 2010). The rainfall was decreased during these 55 years. The recharge of the aquifers is characterized satisfactory and capacity of them remains high.

The water quality varies; the phenomenon of sea intrusion takes place in the coastal areas, because the most of the karstic systems are open to the sea, or due to overexploitation of the aquifers. High salinity has measured in many sampling. The geochemical "pollution" is also presented in many cases, because limestones are soluble, so the chemical reaction of ion exchange is performed.

The island has a significant touristic development; because of this the water needs are increased specially in summer time. The exploitation of the water resources are done by drillings wells and the springs. According to IGME (2010) 97 drills, 30 wells and 18 springs were recorded, but the real number of the subtraction works are definitely bigger than these (figure 3 ).

All these specific hydrological and hydrogeological conditions create the complex groundwater system interacting with the sea in Cephalonia Island. The need of investigating the submarine discharges is increased during the time, it is more imperative in nowadays, because of the climate changes. The exploitation of these outflows to the sea is demanded, as the water deposits are decreased, but the water demands are increased

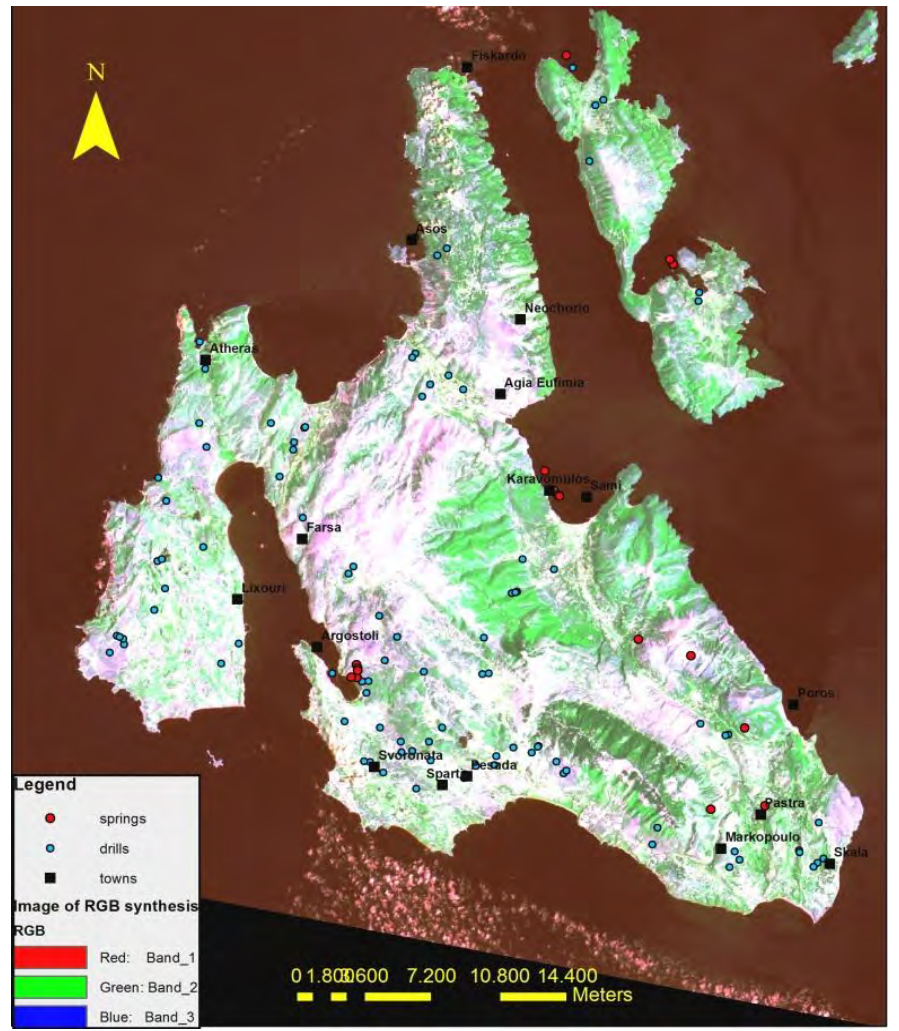

Figure 3 - Satellite image of Cephalonia with the water point subtractions. 


\section{Thermal Infrared Remote Sensing Data Analysis}

Thermal Infrared radiation is emitted from warm objects such as the Earth's surface. Space borne remote sensing of this radiation is carried in certain parts $(3 \mu \mathrm{m}-4 \mu \mathrm{m}$ and $10.5 \mu \mathrm{m}-12.5 \mu \mathrm{m})$ of the thermal infrared region, of the EM Spectrum Thermal Infrared Images are used to quickly assess large areas and acquire useful information and measurements of the earth's land and sea surface temperatures, forest fires etc. Among various satellite derived thermal infrared Images that are currently available, the freely available Landsat TM/ETM are very popular.

Landsat thermal imagery have been used in monitoring evapotranspiration and managing water re sources (Anderson et all 2012), land surface temperature,(Karnielli et al.2001, Jimenez-Munoz et al., 2003), lake surface temperature distributions (Charou et al., 2010). Since the 1970s, both satellite and airborne TIR have been used to detect groundwater discharge, either warmer or cooler than the surrounding surface water, by successfully detecting the contrast in water temperature from different sources. In coastal sea surface temperature variability Landsat Thermal Imagery have been used in synergy with AVHRR data (Thomas, 2003).

In this study Landsat TM/ETM Thermal Infrared images were used to identify surface temperature and specific locations of thermal anomalies. Thermal infrared only measures surface temperatures so its application is limited to the surface seawater. The groundwater temperature is relatively stable and it is as an average temperature of the area, while the temperatures of the surface water are changeable with the changing of the seasons

\subsection{Thermal Variations Detection and Interpretation}

A set of six Landsat 7 Enhanced Thematic Mapper Plus (ETM+) scenes for the years 1984, 1986, 1990, 2000, 2001 and 2005 and one Landsat5 image for the year 2011 was acquired over the Ionian islands have been downloaded from the USGS website (http://glovis.usgs.gov) and used forthe analysis. The Landsat 7 ETM+ of 2005, as all Landsat 7 images collected after May 31, 2003, when the Scan Line Corrector (SLC) failed has data gaps. However the image is still useful for thepart of the image that is to the west of the Cephalonia Island which is not corrupted.

Various image processing and GIS techniques have been used for the analysis of the satellite imagery using the TNTmips software package (www.microimages.com). Pre-processing and image enhancement for the identification of Areas of Interest AOI concerning sea water outflows have been applied. A $6 \mathrm{Km}$ buffer zone around the Cephalonia island was drawn on the Landsat Thermal bands A land mask was created and extracted from all images in order to isolate/separate the sea zone. Variations of intensity in thermal bands were identified. A red color palette was applied to thermal bands for a better visualization (Figure 4). Dark red tones correspond to cold waters while light red to warmer waters.

\subsection{Quantitative Assessment of Thermal Anomalies}

In order to quantitatively assess the thermal anomalies the digital numbers of the original bands were converted to temperature (Celsius) using the relevant standard procedures for Landsat 5 and Landsat 7, available and well used in bibliography (Skianis, 2012) The temperature Map derived from the June, 6 of 2001 Landsat ETM Thermal Band 62 is shown in Figure 6. The sea surface temperatures were estimated for all images and the observed temperatures range from $19.5^{\circ} \mathrm{C}$ to $23.5^{\circ} \mathrm{C}$.

Identified thermal anomalies in Cefalonia's coastal zone, were studied for their possible association with fresh water outflow by consulting topographic and geologic maps. A preliminary analysis reveals, that hydraulic gradients on land result in ground water seepage near shore. Artesian aquifers can extend from shore. In some cases, these deeper aquifers may have fractures in the overlying confining layers allowing fluid exchange between the ground water and the sea. This seems to be the case in Argostoli bay (Figure 5-b), where thermal anomalies have been identified in the Landsat thermal bands. 


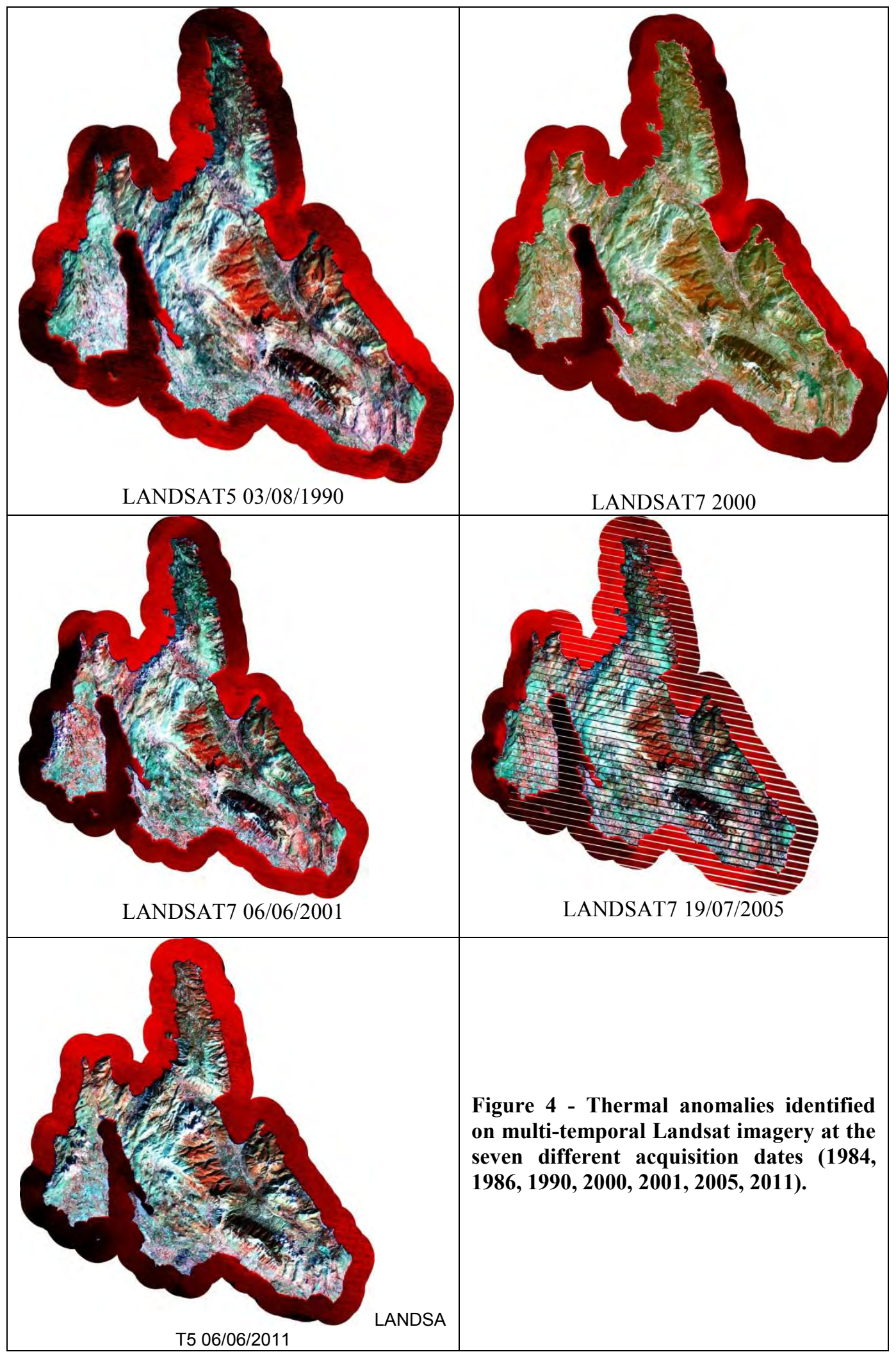

$\underline{\text { XLVII, No } 3 \text { - } 1525}$ 


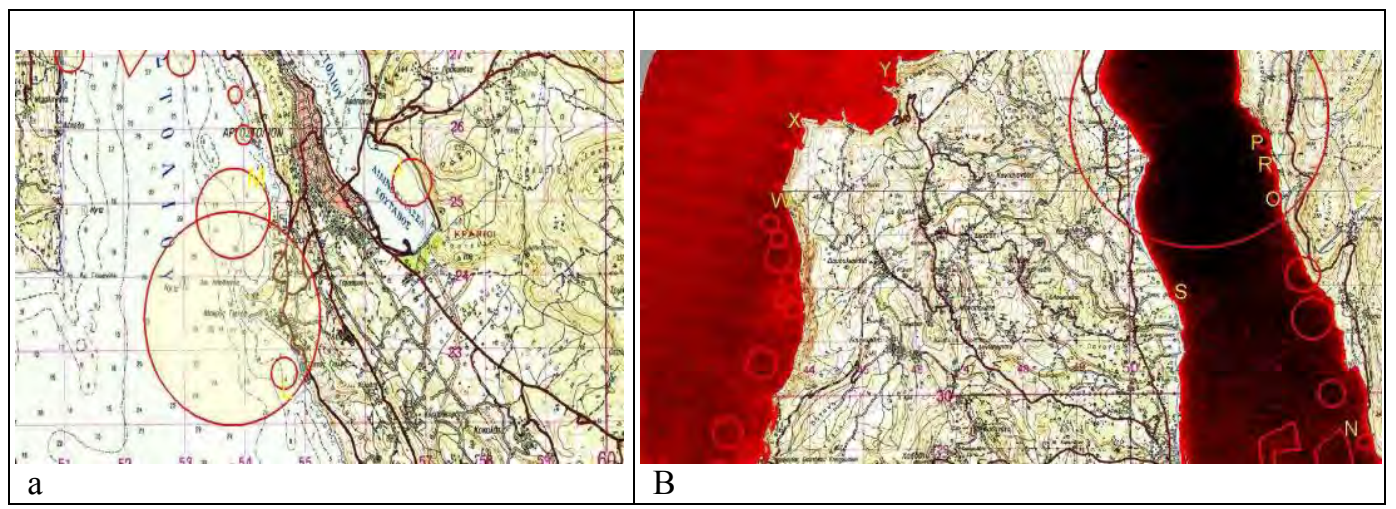

Figure 5 - Topographic Map superimposed in Thermal band with identifiable thermal anomalies.

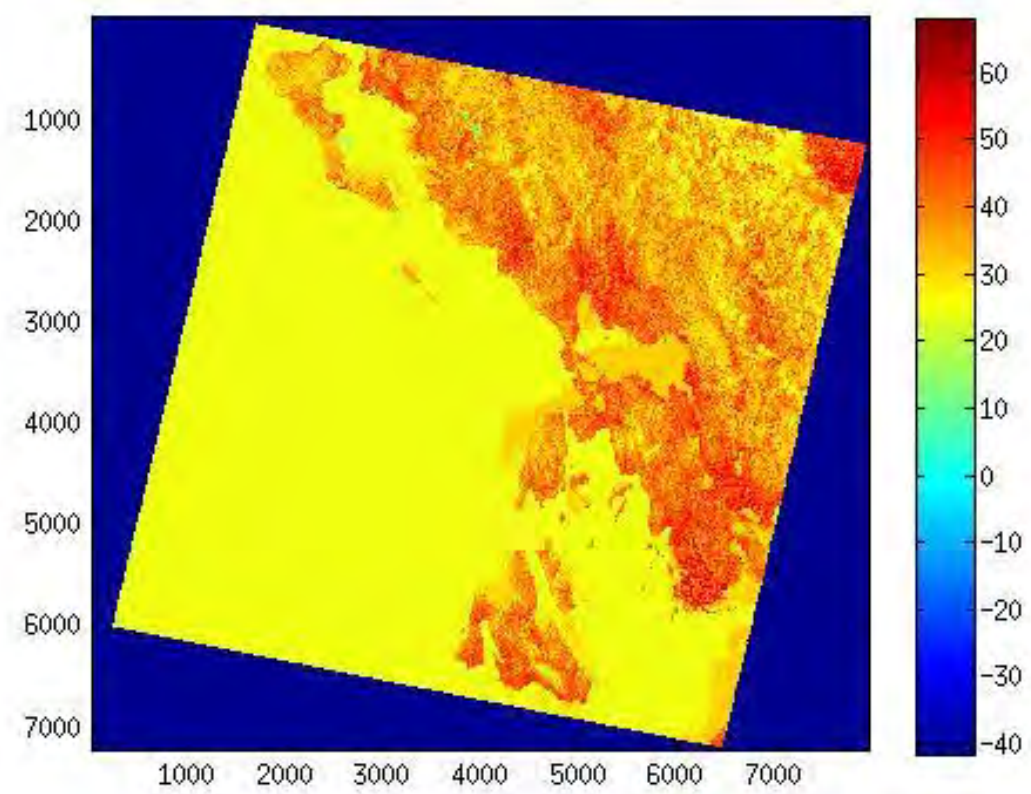

Figure 6 - Temperature Map derived from Thermal band 62 of Landsat 7 (06/06/2001).

In Figure 7, areas with water temperature lower than the surrounding sea water (deep blue colour) are identified. A subset of the imagery of 2001 image was extracted and for this subset the total area of low sea surface temperature was calculated. This is estimated to $1.4 \mathrm{Km}^{2}$.

\section{Results and discussion}

An approach of complementary techniques is applied to localise coastal ground water discharge in the widespread carbonate coastal aquifer of Cephalonia Island. Large coastal discharges have been observed using remote sensing techniques and this provides important information concerning different parameters of interest to a hydrological project. The locations of water outflows seem to be associated with tectonic discontinuities which can be mapped in detail on the satellite images. These discontinuities are used as conduits for the subsurface water flow. The geological 


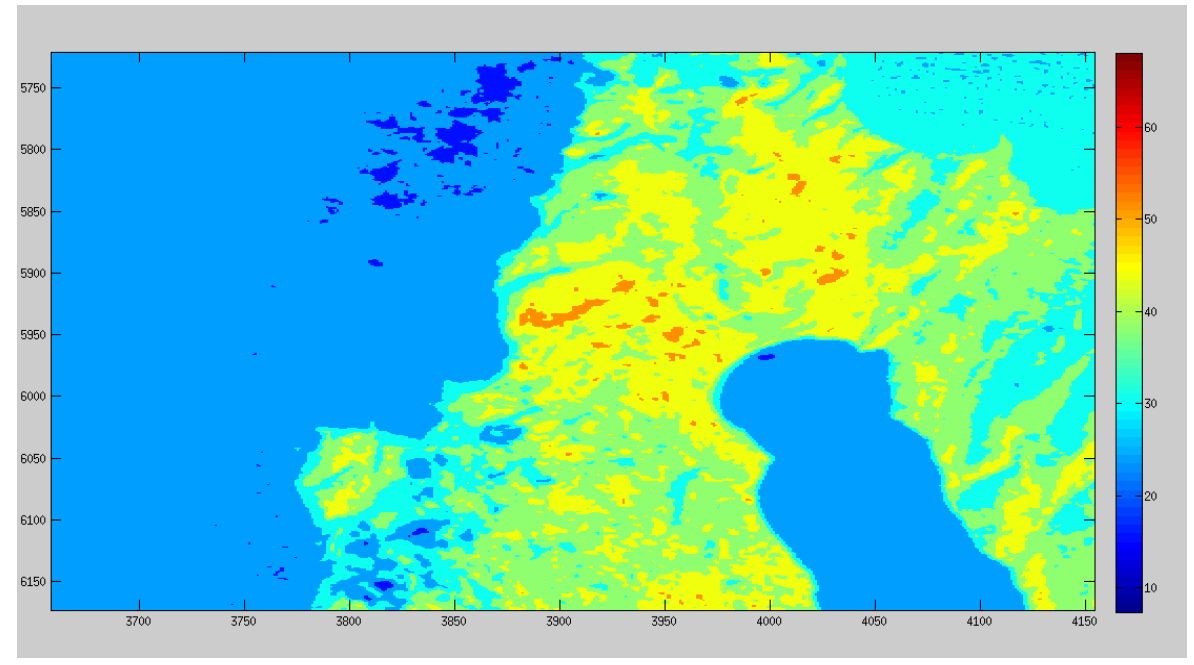

Figure 7 - Areas of low temperature sea water (dark blue).

formations of Cefalonia, which is covered by limestones, create favourable conditions for the occurrence of submarine discharges. Differences in the number and intensity of the identified water outflows between the various satellite image data are attributed to annual / seasonal differences of the hydrologic cycle inland and the ground water system in the coastal aquifers. Differences that are observed between the outflows, that have been recorded in the field and those interpreted on the satellite images, are due to the image resolution of the thermal bands and the prevailing hydrological conditions during the previous year, than the one when the field campaign has been carried out.

Monitoring is supported due to the multi-temporal character of the data. Additionally, satellite data can be analyzed to generate GIS database information required for hydrological studies. Generated database can be used to assess changes that are taking place for the fresh water outflows in coastal areas while tectonic features can be mapped effectively. The added advantage of the proposed approach, is that it makes available to end-users a variety of the data and that it helps in efficient analysis and prediction.

Although Landsat instruments are optimized for terrestrial targets they could be used for the study of possible water outflows into the sea. It is possible to identify thermal anomalies in sea surface and estimate the temperature as well as the area extent of these anomalies. The problem of using Landsat for such study is the large resolution of their images. However the processing of these images along with good knowledge of the geology, topography and hydrology may reveal a good possibility of detecting freshwater out flows. This must be coupled with field investigation and air borne TIR survey. Remote sensing technology has great potential for ground water monitoring and management by providing data to supplement the conventional field data. Considerable basic research and developments are indispensable in the future for enhanced and wide-scale applications of these two highly promising and economically viable techniques in groundwater hydrology.

\section{References}

Al Bassam Abdul Aziz, 2005. Using Remote Sensing and GIS for Submarine freshwater Springs exploration as a Plausible water source in Saudi Arabia" Faculty of Science/King Saud University Eng. Hiba Mohammed Tiro, GIS Department Manager / Engineering Department / Saudi Oger LTD.

Anderson M.C., Allen R., Morse A. and Kustas W. 2012. Use of Landsat thermal imagery in monitoring evapotranspiration and managing water resources, Remote Sensing of Environment, doi: 10.1016/j.rse.2011.08.025.

$\underline{\text { XLVII, No } 3-1527}$ 
Ahlgren S. and Holmlund J. 2002. Outcrop Scans Give New View. American Association of Petrolum Geologists Explorer, July 2002. Available online at: http://www.aapg.org/explorer/geophysical_corner/2002/07gpc.cfm

Charou E, Stefouli M., Katsimbra E. and Chioni A. 2010. Monitoring lake hydraulics using remote sensing techniques in West Macedonia, $6^{\text {th }}$ International Symposium on Environmental Hydraulics, Athens, Greece, 887-892.

IGME 2010. Recording and evaluating of groundwater's hydrogeological characteristics and the aquifer system of Greece, ${ }^{3 r d}$ Community Support Framework, Athens.

Jimenez-Munoz J.C. and Sobrino J.A. 2003. A generalized single-channel method for retrieving land surface temperature from remote sensing data, Journal of Geophysical Research, 108, doi: 10.1029/2003JD003480.

Karnieli Q. and Berliner P. 2001. A mono-window algorithm for retrieving land surface temperature from Landsat TM data and its application to the Israel-Egypt border region, International Journal of Remote Sensing, 22, 3719-3746.

Koumantakis I.E. 1989. Research of the aquifer system of Kefalonia Island: The regulation of the lake-spring of Megali Avuthos. Proposals for the exploitation of south-east Cephalonia Island. School of Mining and Metallurgy Engineering, Section of Geological Sciences, NTUA.

Skianis G., Nikolakopoulos K. and Vaiopoulos D. 2012. Remote sensing, IWN Editions.

Stefouli M., Tsompos P., 2004. Identification and monitoring of fresh water outflows in coastal areas:pilot study on Psahna area/Evia island Greece, Bulletin of the Geological Society of Greece, vol. XXXVI, Thessaloniki.

Thomas A., Byrne D. and Weatherbe R. 2002. Coastal sea surface temperature variability from Landsat infrared data, Remote Sensing of Environment, 81, 262-272.

http://landsathandbook.gsfc.nasa.gov/data_prod/ 